\title{
Antifeedant activity and field evaluation of spinetoram 12 SC against termite, Odontotermes obesus on sugarcane
}

N. Muthukrishnan and M. Visnupriya* Department of Agricultural Entomology, Tamil Nadu Agricultural University, Coimbatore (T.N.) India

\section{ARITCLE INFO}

Received : 10.04 .2019

Revised : 15.08 .2019

Accepted : 01.09.2019

\section{KEY WORDS :}

Sugarcane, Spinetoram 12 SC, Antifeedant activity, Odontotermes obesus, Sett treatment, Soil drenching
*Corresponding author:

Email : haivinuento@gmail.com

\begin{abstract}
In this experiment a new insecticide molecule, spinetoram $12 \mathrm{SC}$ was taken up to evaluate its antifeedant and repellent activity in laboratory and efficacy in the field with different mode of application against termite control. Laboratory experiments were conducted in Insectary, Agricultural College and Research Institute, Madurai. Field experiments were laid out in Randomized Block Design at farmer's field located in Mandhikanmai village, Kalayarkoil Block, Sivagangai district during 2014-2015 and to study the effect of sett treatment and soil drenching of spinetoram $12 \mathrm{SC}$ with variety $\mathrm{CO} 86032$. At the time of planting, sugarcane setts were treated with various doses of spinetoram $12 \mathrm{SC}(90,120$, 150 and $180 \mathrm{~g}$ a.i./ha) and covered with soil. After planting in 35 days old sugarcane soil drenching treatment was also effected with the same dose of sett treatment. Imidacloprid 20 SL, Rynaxypyr $20 \mathrm{SC}$ and chlorpyrifos $20 \mathrm{EC}$ were standard checks. The cumulative mean food consumption was minimum $0.71 \mathrm{~g}, 0.78 \mathrm{~g}, 1.02 \mathrm{~g}, 1.23 \mathrm{~g}, 1.44 \mathrm{~g}$ and $1.56 \mathrm{~g}$ in various concentrations of spinetoram viz., 360,300, 240, 180, 120 and $60 \mathrm{ppm}$, respectively. The highest mean per cent repellent action was noticed in spinetoram $360 \mathrm{ppm}$ and 300 ppm (93.4 and $91.2 \%$, respectively) at 12 HAT. Field experiments were inferred that spinetoram $12 \mathrm{SC} 180$ and $150 \mathrm{~g}$ a.i./ha were significantly effective in minimizing number of termite colony per plot, number of termites per colony and per cent sett damage in both sett treatment and soil drenching methods.
\end{abstract}

How to view point the article : Muthukrishnan, N. and Visnupriya, M. (2019). Antifeedant activity and field evaluation of spinetoram $12 \mathrm{SC}$ against termite, Odontotermes obesus on sugarcane. Internat. J. Plant Protec., 12(2) : 87-93, DOI : 10.15740/HAS/IJPP/12.2/87-93, Copyright@ 2019: Hind Agri-Horticultural Society. 